\title{
Pretreatment and on-treatment indicators of virologic breakthrough of lamivudine therapy in chronic hepatitis B patients: an Egyptian study
}

\author{
M. F. MONTASSER ${ }^{1}$, N. A. ABDELKADER ${ }^{1}$, S. A. ISMAIL ${ }^{2}$, I. M. F. MONTASSER ${ }^{1}$ \\ ${ }^{1}$ Department of Tropical Medicine, Faculty of Medicine, Ain Shams University, Cairo, Egypt; ${ }^{2}$ Department of Tropical Medicine, \\ National Hepatology and Tropical Medicine Research Institute Cairo, Egypt
}

Received January 16, 2014; accepted July 31, 2014

\begin{abstract}
Summary. - The primary objectives of hepatitis B treatment include improved clinical and histological progression as well as virus eradication. For many years, lamivudine was a first-line therapy for treating hepatitis B virus (HBV) infection. However, its long-term use is associated with high resistance rates (up to $70 \%$ after 5 years) due to mutations in the viral YMDD motif. The purpose of this study was to outline factors responsible for the development of viral resistance during long-term lamivudine therapy. Initially, 230 patients receiving lamivudine therapy for chronic hepatitis $\mathrm{B}(\mathrm{CHB})$ infection were enrolled in the study. All subjects received follow-ups in the first year to assess viral and biochemical responses. Only 136 and 104 patients received follow-up assessments during the second and third years of treatment, respectively. Viral breakthrough (VBT) occurred in 49 of 230 patients (21.3\%). Hepatitis B "e" antigen (HBeAg) status before treatment was significantly associated with VBT in the first 2 years of treatment; however, this effect was not significant in the third year. Pre-treatment HBV DNA levels were predictive of VBT in the HBeAg-positive subgroup after all years of treatment $(\mathrm{P}=0.001, \mathrm{P}=0.002$, and $\mathrm{P}=0.002$, respectively). These levels were also predictive in the HBeAg-negative subgroup after 1 year of treatment $(\mathrm{P}=0.001)$. In resource-poor communities, financial concerns drive the selection of antiviral therapy to treat CHB. Lamivudine monotherapy is a relatively cheap and effective treatment to manage CHB. However, consistent follow-ups and treatment modifications appear essential to prevent long-term treatment failure.
\end{abstract}

Keywords: chronic hepatitis B; lamivudine; predictors of response

\section{Introduction}

Chronic hepatitis B virus (HBV) infection is a global health problem: about 2 billions of people have a past or present HBV infection; of these, 350 millions are chronic carriers of HBV. Each year, approximately 1 million people die of diseases associated with HBV infection, including liver failure, cirrhosis, and primary hepatocellular carcinoma (Yi et al., 2012).

E-mail: imanfawzy@gmail.com; phone: +20106065333.

Abbreviations: $\mathrm{ALT}=$ alanine aminotransferase $\mathrm{CHB}=$ chronic hepatitis B; EASL = European Association for the Study of the Liver; $\mathrm{HBeAg}=$ hepatitis B "e" antigen; $\mathrm{HBsAg}=$ hepatitis B surface antigen; $\mathrm{HBV}=$ hepatitis $\mathrm{B}$ virus; $\mathrm{NA}=$ nucleos $(\mathrm{t})$ ide analogue; VBT $=$ viral breakthrough
Due to inadequate measures to confine the spread of infection, $\mathrm{HBV}$ has a high prevalence in many developing countries (Abbas and Siddiqui, 2011). Studies in the Middle East show the prevalence of the hepatitis B surface antigen (HBsAg) to range from 3\% to 11\% in Egypt (Qirbi et al., 2001).

The primary objectives of hepatitis B treatment include improved clinical and histological progressions and virus eradication (European Association for the Study of the Liver [EASL], 2012). Long-term lamivudine use is associated with a high rate of resistance (up to $70 \%$ by the end of 5 years) due to mutations in the viral YMDD motif (Chang et al., 2004).

Viral breakthrough (VBT) is usually followed by biochemical breakthrough, defined by elevated alanine ami- 
notransferase (ALT) levels during treatment in patients who had experienced an initial treatment response. Development of viral mutations against antiviral therapies can negate the initial response, and in some cases, lead to hepatitis flares and hepatic decompensation. These mutations can be detected months or even years before biochemical breakthrough occurs (Fung et al., 2006). Thus, early detection and intervention can prevent serious conditions, particularly in patients who are immunosuppressed or with underlying cirrhosis. Another potential consequence of drug-resistant HBV mutants is cross-resistance with other nucleos(t)ide analogues (NAs), thus limiting future treatment options (Yim et al., 2006).

Follow-up of patients receiving continued lamivudine treatment has revealed decreased virologic and biochemical responses over time due to viral development of drugresistance mutations. Several studies reported that patients with sustained viral suppression had lower rates of hepatic decompensation and liver-related mortality (Papatheodoridis et al., 2005).

The purpose of this study was to determine which pretreatment and on-treatment factors are associated with the development of viral resistance and VBT during long-term lamivudine therapy.

\section{Materials and Methods}

Patients. This retrospective study included patients diagnosed with chronic HBV who received lamivudine therapy at the Hepatology Clinic in the National Hepatology \& Tropical Medicine Research Institute (NHTMRI) and Tropical Medicine Department in Cairo, Egypt over three years. The study was approved by the Ethics Committee of National Hepatology \& Tropical Medicine Research Institute and the Tropical Medicine Department at Ain Shams University Hospitals, Cairo, Egypt, in accordance with local research governance requirements. The trial was registered with the federal clearinghouse for randomized trials: ClinicalTrials.gov (NCT01548820).

Definitions. A biochemical response was defined as normalization of serum ALT levels after the initiation of therapy. A virologic response corresponded to a reduction of HBV DNA to levels undetectable by real-time PCR (HBV PCR assay by real time mx-3000, Qiagen). A partial response was defined as a decrease greater than $1 \log _{10} \mathrm{IU} / \mathrm{ml}$ in HBV DNA levels at month 6 of lamivudine therapy, from baseline levels detectable by real-time PCR assay. A primary non-response was defined as a decrease less than $1 \log _{10} \mathrm{IU} / \mathrm{ml}$ in HBV DNA levels from baseline at month 3 of lamivudine therapy (EASL, 2012). Viral breakthrough was considered as the first manifestation of antiviral drug resistance and was defined as a 10-fold increase in serum HBV DNA levels from their lowest point during treatment in patients with an initial virologic response (Lok and McMahon, 2009); it was also defined as the detection of HBV DNA after virologic response (Chae et al., 2007).

Inclusion criteria. Adult Egyptian patients serum-positive for HBsAg for more than 6 months with HBV viraemia above 2,000 IU/ $\mathrm{ml}(10,000$ copies $/ \mathrm{ml})$ were enrolled in the study. Study participants received lamivudine monotherapy at the recommended dose of 100 mg administered daily. Patients were evaluated every 3 months for laboratory abnormalities.

Exclusion criteria. Patients with positive serology results for IgM antibodies against hepatitis B core antigen (anti-HBc IgM) or hepatitis $\mathrm{C}$ virus (HCV) were excluded from the study. Patients diagnosed with hepatocellular carcinoma were also excluded.

Patient assessment. Full medical histories were collected and clinical examinations performed on all study participants. Examinations included laboratory testing to measure complete blood count (CBC), international normalized ratio (INR), liver and renal profiles including ALT assay (Bais et al., 2006), alpha-fetoprotein (AFP) levels, viral markers, and HBV DNA levels by quantitative PCR. Abdominal ultrasound imaging was also performed on study participants.

Patients were monitored for VBT after 1, 2, and 3 years of lamivudine treatment to identify pre-treatment and on-treatment factors associated with breakthrough.

Statistical analysis. IBM SPSS Statistics for Windows, version 19.0 (IBM Corp., Armonk, USA) was used for data analysis. Quantitative parametric measures were expressed as mean $\pm S D$, quantitative non-parametric measures as median and percentiles, and both numbers and percentages were used to express categorized data. Student's t, Wilcoxon rank-sum, Spearman's ranked correlation, and Chi square tests were used to analyze data. Probability of error (P) values $<0.05$ were considered statistically significant.

\section{Results}

This retrospective study included 230 patients at the outpatient clinic at the NHTMRI and Tropical Medicine Department in Cairo, Egypt with chronic HBV infections and matched the inclusion criteria; study participants received lamivudine treatment (100 mg once daily) and received follow-ups to assess virologic and biochemical responses to treatment and were tested for VBT. Lamivudine was selected as it was the only oral antiviral CHB therapy available under medical insurance coverage at the beginning of the study period.

Two hundred and thirty patients started the study and were followed up during the first year; however, only 136 and 104 patients received follow-ups during the second and third years. Patients who did not respond to treatment and those that developed VBT and received alternative drug therapies were excluded from analysis. There were 34 women $(14.8 \%)$ and 196 men $(85.2 \%)$ in the study population. Their mean age was $34.52 \pm 8.12$ years (average, 
Table 1. Serum ALT and HBV DNA levels in CHB patients at various lamivudune treatment statuses

\begin{tabular}{|c|c|c|c|c|c|}
\hline \multirow{2}{*}{\multicolumn{2}{|c|}{ Treatment status }} & \multicolumn{4}{|c|}{ ALT (IU/l) } \\
\hline & & Mean \pm SD & Median & $\mathrm{IQR}^{*}$ & P-value \\
\hline \multicolumn{2}{|c|}{ Pre-treatment } & $56.23 \pm 54.62$ & 47.00 & $32.34-66.15$ & \multirow{5}{*}{$<0.01$} \\
\hline \multirow{5}{*}{ Treatment } & 6 months & $36.52 \pm 22.33$ & 34.00 & $22.00-42.00$ & \\
\hline & 1 year & $35.76 \pm 20.61$ & 30.00 & $22.00-40.00$ & \\
\hline & 2 years & $32.55 \pm 19.81$ & 28.00 & $20.00-35.00$ & \\
\hline & 3 years & $31.34 \pm 19.85$ & 29.00 & $21.00-37.00$ & \\
\hline & & & $\mathrm{A}$ in $\mathrm{HBe}$ & patiens ${ }^{* *}$ & \\
\hline Pre-treatm & & $11.33 \pm 2.43$ & 10.62 & $8.70-13.23$ & \\
\hline & 6 months & $2.77 \pm 3.44$ & 0.00 & $0.00-4.79$ & \\
\hline & 1 year & $1.42 \pm 2.69$ & 0.00 & $0.00-0.00$ & $<0.01$ \\
\hline Ireatment & 2 years & $1.12 \pm 1.32$ & 0.00 & $0.00-0.00$ & \\
\hline & 3 years & $0.63 \pm 1.20$ & 0.00 & $0.00-0.00$ & \\
\hline & & & $\mathrm{A}$ in $\mathrm{HBe}$ & patients $^{\star *}$ & \\
\hline Pre-treatm & & $5.33 \pm 2.43$ & 4.62 & $3.70-6.23$ & \\
\hline & 6 months & $2.77 \pm 2.17$ & 0.00 & $0.00-3.26$ & \\
\hline & 1 year & $1.42 \pm 1.22$ & 0.00 & $0.00-0.00$ & $<0.01$ \\
\hline Treatment & 2 years & $0.73 \pm 1.21$ & 0.00 & $0.00-0.00$ & \\
\hline & 3 years & $0.32 \pm 1.10$ & 0.00 & $0.00-0.00$ & \\
\hline
\end{tabular}

${ }^{\star} \mathrm{IQR}$; interquartile range; ${ }^{\star *} \log$ number of viral genome IU per $\mathrm{ml}$.

33 years). We have observed a significant drop in mean and median ALT levels after 6 months and up to 3 years of treatment. We also observed a statistically significant drop in mean and median HBV DNA levels in the same time frame in both $\mathrm{HBeAg}$-positive and HBeAg-negative subgroups (Table 1).

Among the studied population (230); primary virologic response was detected in 99 patients (43\%), partial response in 100 patients $(43.5 \%)$ and thirty one patients (13.5\%) had primary non response (Table 2).

Pre-treatment factors were analyzed to determine their effect on the development of VBT during treatment. There were no significant associations between age, gender, and pre-treatment ALT levels and VBT rates for all treatment durations (data not shown).

Table 3 shows that the pre-treatment HBeAg status was significantly associated with VBT during the first and second

Table 2. Response to 6-month-lamivudine therapy in CHB patients

\begin{tabular}{ll}
\hline Patients & No. $(\%)$ \\
\hline Total & $230(100)$ \\
\hline Virologic response & $99(43.0)$ \\
\hline Partial response & $100(43.5)$ \\
\hline Primary non-response & $31(13.5)$ \\
\hline
\end{tabular}

†Values are given as number (percentage). years of treatment; however, this effect was not significant during the third year. Pre-treatment HBV DNA levels were significantly associated with VBT in the HBeAg-positive subgroup during all years of treatment. A significant relationship existed between pre-treatment HBV DNA levels and the development of VBT in the HBeAg-negative subgroup only during the first year of treatment (Table 4).

Only 1 (1.3\%) HBeAg-positive patient showed HBsAg seroconversion after 1 year of lamivudine therapy, and no HBeAg-negative patient showed HBsAg seroconversion in the same treatment duration. Among HBeAg-positive patients, $22(28.2 \%)$ showed HBeAg seroconversion after 1 year of drug therapy.

\section{Discussion}

A high prevalence of $\mathrm{HBeAg-negative} \mathrm{variants} \mathrm{and} \mathrm{inac-}$ tive HBsAg carrier states exists in Egypt, where HBeAgnegative variants account for more than $80 \%$ of $\mathrm{CHB}$ cases in older age groups (22-45 years). Inactive HBsAg carriers represent nearly $33 \%$ of chronic hepatitis B infections (ElZayadi, 2007).

Study participants were divided into 2 subgroups based on the pre-treatment $\mathrm{HBeAg}$ status to study differences in treatment response and VBT rate and to evaluate the usefulness of pre-treatment HBeAg status and HBV DNA levels as predictors of VBT. The study population was predominantly 
Table 3. Influence of the pretreatment $\mathrm{HBeAg}$ status on the rate of viral breakthrough in $\mathrm{CHB}$ patients treated with lamivudine

\begin{tabular}{|c|c|c|c|c|c|}
\hline \multirow{2}{*}{ Period of LAM therapy } & \multicolumn{2}{|c|}{ Pretreatment HbeAg-negative patients } & \multicolumn{2}{|c|}{ Pretreatment $\mathrm{HBeAg}$-positive patients } & \multirow{2}{*}{ P-value } \\
\hline & Total & No. (\%) of patients showing VBT & Total & No. (\%) of patients showing VBT & \\
\hline 1 year & 152 & $20(13.2 \%)$ & 78 & $29(37.2 \%)$ & 0.03 \\
\hline 2 years & 104 & $21(20.2 \%)$ & 32 & $11(34.4 \%)$ & 0.8 \\
\hline 3 years & 83 & $23(27.7 \%)$ & 21 & $8(38.1 \%)$ & 0.5 \\
\hline
\end{tabular}

VBT $=$ viral breakthrough

Table 4. Influence of the pre-treatment $\mathrm{HBeAg}$ and $\mathrm{HBV}$ DNA statuses on the rate of viral breakthrough in $\mathrm{CHB}$ patients treated with lamivudine

\begin{tabular}{|c|c|c|c|c|}
\hline Period of LAM therapy & HbeAg status & No. (\%) of patients without VBT & No. (\%) of patients with VBT & P-value \\
\hline \multirow{2}{*}{1 year } & Negative & $102(68 \%)$ & $20(40.8 \%)$ & \multirow[t]{2}{*}{0.001} \\
\hline & Positive & $48(32 \%)$ & $29(59.2 \%)$ & \\
\hline \multirow{2}{*}{2 years } & Negative & $83(79.8 \%)$ & $21(65.6 \%)$ & \multirow[t]{2}{*}{0.024} \\
\hline & Positive & $21(20.2 \%)$ & $11(34.4 \%)$ & \\
\hline \multirow{4}{*}{3 years } & Negative & $60(82.2 \%)$ & $23(74.2 \%)$ & \multirow[t]{2}{*}{0.182} \\
\hline & Positive & $13(17.8 \%)$ & $8(25.8 \%)$ & \\
\hline & \multicolumn{3}{|c|}{ HBV DNA $\left(\right.$ mean \pm SD) ${ }^{\star *}$} & \multirow{2}{*}{ P-value } \\
\hline & VBT absent & VBT present & & \\
\hline 1 year & $8.77 \pm 4.13$ & $17.14 \pm 5.23$ & & $0.001^{*}$ \\
\hline 2 years & $8.19 \pm 3.76$ & $11.73 \pm 3.75$ & & $0.001^{*}$ \\
\hline 3 years & $8.75 \pm 3.55$ & $13.24 \pm 2.30$ & & $0.001^{*}$ \\
\hline
\end{tabular}

${ }^{\star}$ Statistically significant difference. $\uparrow$ Values are given as mean \pm SD or number (percentage). ${ }^{\star *} \log$ number of viral genome IU per ml.

HBeAg-negative, with 152 of 230 patients (66.1\%) comprising this subgroup.

Only $1 \mathrm{HBeAg}$-positive patient (1.3\%) showed HBsAg seroconversion after 1 year of lamivudine treatment. This result is concordant with reports by Lau et al. (2005) and Janssen et al. (2005), who found HBsAg seroconversion rates of $1 \%$ in HBeAg-positive patients after 1 year of therapy. No HBeAgnegative patient in this study showed seroconversion after 1 year of lamivudine therapy. Marcellin et al. (2004) and Lai et al. (2007) also reported no seroconversion among HBeAgpositive patients after 1 year of lamivudine therapy.

Among HBeAg-positive patients, 22 (28.2\%) showed $\mathrm{HBeAg}$ seroconversion after 1 year of lamivudine therapy. Comparable results were reported by other case series studies that reported $32 \%$ and $18 \% \mathrm{HBeAg}$ seroconversion, respectively (Chang et al., 2006; Liaw et al., 2009).

The seroconversion rate reached $93.7 \%$ in patients who received follow-ups in the second year of treatment, after exclusion of patients who did not respond to treatment or had developed VBT. The seroconversion rate was $100 \%$ by the third year of the study. This finding is similar to a report by Reijnders et al. (2010), who found that anti-HBe seroconversion rates increased with continued NA therapy, and were affected by the development of drug resistance.

Lamivudine has been a long-time first-line therapeutic agent for the management of $\mathrm{CHB}$, mainly due to its relatively low cost (Lok and McMahon, 2009), good clinical tolerability, and moderate antiviral efficacy (Wiegand et al., 2010). However, EASL guidelines updated in 2012 instead recommend entecavir and tenofovir as the initial treatments. Because they are potent HBV inhibitors with high barriers to resistance, these drugs can be confidently used as firstline monotherapies. The other 3 NAs are recommended for treating $\mathrm{CHB}$ only when the more potent drugs are not available or appropriate. Lamivudine is an inexpensive agent, but engenders very high rates of resistance when used as a long-term monotherapy (Lok et al., 2000; Marcellin et al., 2011).

In this study, virologic response was assessed after 1, 2, and 3 years of lamivudine therapy. After 1 year of lamivudine treatment, 137 of 230 patients (59.6\%) showed virologic response. There was no significant difference in the response rate between subgroups after 1 year of therapy. In the HBeAg-positive subgroup, 33 of 78 (42.3\%) patients showed virologic response. This is consistent with findings by Chang et al. (2006) and Lai et al. (2007), who reported virologic response rates of $36 \%$ and $43 \%$, respectively, in $\mathrm{HBeAg}$-positive patients after 1 year of lamivudine therapy. The present study observed a virologic response in 104 of $152(68.4 \%)$ patients in the HBeAg-negative subgroup. This finding is consistent with findings by Marcellin et al. (2004) and Lai et al. (2007) who reported a virologic response rate 
of $70 \%$ and $73 \%$, respectively, in HBeAg-negative patients after 1 year of lamivudine therapy. Non-response was noted in 44 out of $230(19.1 \%)$ patients.

VBT occurred in 49 of 230 patients (21.3\%). In addition, there was a significant difference in the rate of VBT between the 2 subgroups after 1 year of lamivudine therapy.

In our study, long-term treatment with lamivudine resulted in progressively higher VBT rates. After 2 years of therapy, 32 of 136 patients (23.5\%) showed VBT; the cumulative rate was for 2 years $35.2 \%$ ( 81 out of 230 patients). After 3 years of therapy, 31 of 104 patients (29.8\%) showed VBT, corresponding to a cumulative rate of $48.7 \%$ (112 of 230 patients) (Table 3 ). These findings are in agreement with those of Pawlotsky et al. (2008), who reported a cumulative resistance rate in lamivudine therapy after 1, 2, and 3 years of $24 \%, 38 \%$, and $49 \%$, respectively.

The subgroups showed different VBT rates during the course of treatment. The HBeAg-positive subgroup had VBT rates of $37.2 \%, 34.4 \%$, and $38.1 \%$ after 1,2 , and 3 years, respectively. This observation is concordant with Lau et al.(2005), who reported VBT rates of 35\%, 37\%, and $42 \%$ in HBeAg-positive patients after 1,2, and 3 years of lamivudine therapy, respectively. The HBeAg-negative subgroup had VBT rates of $13.2 \%, 20.2 \%$, and $27.7 \%$ after 1,2 , and 3 years of treatment, respectively, similar to results reported by Marcellin et al. (2004), of VBT rates among HBeAg-negative patients of $15 \%, 24 \%$, and $33 \%$ after 1,2, and 3 years of lamivudine therapy, respectively (Table 3 ).

We studied the relationship between age, gender, pretreatment HBeAg status, pre-treatment ALT levels, and pre-treatment HBV DNA levels to determine if these various pre-treatment factors were possible predictors of VBT.

We observed a highly significant relationship between pre-treatment HBeAg status and VBT during the first and second years of treatment. However, this pre-treatment status did not significantly affect the development of VBT in the third year of treatment. These results disagree with those of studies conducted by Yuen (2001), Hadziyannis et al. (2007), and Alam et al. (2008), who found no significant relationship between the pre-treatment $\mathrm{HBeAg}$ status and rates of VBT.

Pre-treatment ALT levels were not significant predictors of VBT for any year. We included in our analysis only those patients with ALT levels twice the normal limit. Our findings agree with those of Alam et al. (2008) who also found no significant relationship between pre-treatment ALT levels and development of VBT.

We observed a significant relationship between pretreatment HBV DNA levels and VBT among HBeAg-positive patients during the first, second, and third years of treatment follow up. This result is similar to the findings by Chae et al. (2007) who reported a significant relationship between pre-treatment HBV DNA levels and development of VBT. However, Yuen et al. (2007) reported that baseline HBV DNA levels were not significantly related to VBT occurrence in $\mathrm{HBeAg}$-positive patients on lamivudine therapy. A significant relationship also existed between pre-treatment HBV DNA levels and development of VBT in HBeAg-negative patients during the first year of treatment. However, this relationship was not significant in later years. In contrast, Hadziyannis et al. (2007) found no significant relationship between pre-treatment HBV DNA levels and VBT in HBeAg-negative patients, a result also corroborated by a study conducted by Thompson et al. (2007).

On-treatment factors, including $\mathrm{HBeAg}$ status and ALT and HBV DNA levels, were measured at 6 months to determine if these factors were possible predictors of VBT. We observed a significant relationship between HBeAg status during treatment and development of VBT in the first and second years of treatment. Alam et al. (2008) also observed that sustained HBeAg-positive status within 1 year of lamivudine therapy was highly predictive of future VBT.

We found no significant relationship between ALT levels during treatment and VBT. This finding is similar to Chae et al. (2007) and Alam et al. (2008), who also reported that ALT levels during treatment were not predictive of VBT, presumably because VBT usually precedes biochemical breakthrough.

Several studies have found on-treatment serum HBV DNA levels to be predictive of lamivudine resistance (Lai et al., 2007; Hadziyannis et al., 2007; Thompson et al., 2007). In our study, patients who had not developed a virologic response after 6 months of treatment were more likely to develop VBT later.

A highly significant relationship was found between ontreatment HBV DNA levels and VBT rates after 6 months and 1 year of treatment, respectively $(\mathrm{P}<0.001)$. The 6 -month HBV DNA levels remained significantly related during the second year of therapy $(\mathrm{P}<0.005)$, but the association was not significant during the third year of treatment. Yuen $e t$ al. (2001) also reported a similar finding in $159 \mathrm{HBeAg}$-positive $\mathrm{CHB}$ patients treated with lamivudine and evaluated for a median period of 30 months: those with HBV DNA levels greater than 103 copies/ml at 6 months had a $63 \%$ chance of developing the YMDD mutation associated with VBT, whereas those with HBV DNA levels less than 103 copies/ml had only a $13 \%$ chance of developing the mutation.

We observed a significant relationship between HBV DNA levels at 6 months of treatment and occurrence of VBT during the first and second years in the HBeAg-negative subgroup $(\mathrm{P}<0.005)$. However, the relationship was not significant in the third year of treatment. This observation is concordant with a study of $139 \mathrm{HBeAg}$-negative patients treated with lamivudine for 2 years: Chan et al. (2007) reported a correlation between 2-year lamivudine resistance rates and serum HBV DNA levels at 6 months, a finding also consistent with Hadziyannis et al. (2007), who in- 
vestigated the predictive value of serum HBV DNA levels during treatment in a study involving $156 \mathrm{HBeAg}$-negative patients who received prolonged lamivudine treatment. In their analysis, undetectable HBV DNA levels at 12 and 24 weeks of lamivudine treatment had $93 \%$ and $72 \%$ predictive values for sustained virologic response at 2 and more than 4 years, respectively.

Our analyses showed a positive correlation between preand post-treatment HBV DNA levels and VBT occurrence at 6 months and 1,2, and 3 years in the HBeAg-positive subgroup. These levels were also positively correlated in the HBeAg-negative subgroup at 6 months and 1 year. However, there was no significant positive correlation at 2 or 3 years of treatment. Alam et al.(2008) reported a similar significant positive correlation between baseline HBV DNA levels and VBT in both $\mathrm{HBeAg}$-positive and HBeAg-negative patients in a study of 423 patients followed up for 78 months $(\mathrm{P}=$ 0.005).

Multivariate analysis of pre-treatment factors including age, gender, ALT, and HBV DNA levels, and HBeAg status revealed HBV DNA levels to be predictive of VBT in the HBeAg-positive subgroup after 1, 2, and 3 years of treatment. Pre-treatment HBV DNA levels were also predictive of VBT in the HBeAg-negative subgroup after 1 and 2 years of treatment. However, no factors were significantly predictive of VBT after 3 years of treatment. In contrast, Thompson et al.(2007) reported resistance rates of $6 \%, 31 \%$, and $51 \%$ at 12,24 , and 48 months, respectively, in a prospective study of 85 patients with $\mathrm{CHB}$ who were treated with lamivudine. Multivariate analysis identified the presence of the HBV precore variant, high baseline ALT levels, and persistent viraemia at 24 weeks as independent predictors of early lamivudine resistance. Our findings are also contradictory to those of Alam et al. (2008), who found persistent levels of HBV DNA detected by PCR at 6 months of treatment to be an independent predictor of lamivudine resistance by multivariate analysis in a study of 423 chronic HBV HBeAg-positive and HBeAg-negative patients who had not previously received treatment.

In summary, our data show that lamivudine monotherapy is a relatively cheap and effective treatment for management of $\mathrm{CHB}$ in carefully selected patients, and that pre-treatment and on-treatment level of HBV DNA and rates of HBeAg seroconversion are helpful predictors of treatment response as well as markers to inform continued treatment strategies.

\section{References}

Abbas Z, Siddiqui AR (2011): Management of hepatitis B in developing countries. World J. Hepatol. 27, 292-299. http:// dx.doi.org/10.4254/wjh.v3.i12.292
Alam S, Azam G, Mustafa G, Ahmad N, Islam B, Podder PK, Khan $M$ et al. (2008): Pretreatment and on-treatment predictors of viral breakthrough in lamivudine therapy for chronic hepatitis B. Hepatol. Int. 2, 494-497. http:// dx.doi.org/10.1007/s12072-008-9095-9

Bais R, Panteghini M, (2006): In Burtis CA, Ashwood ER, Bruns DE (Eds): Tietz Textbook of Clinical Chemistry and Molecular Diagnostics. 4 th ed. Missouri: Saunders, pp. 191-218.

Chae HB, Hann HW (2007): Time for an active antiviral therapy for hepatitis B: An update on the management of hepatitis B virus infection. Ther. Clin. Risk Manag. 3, 605-612.

Chang TT, Lai CL, Chien RN, Guan R, Lim SG, Lee CM, Ng KY, Nicholls GJ, Dent JC, Leung NW (2004): Four years of lamivudine treatment in Chinese patients with chronic hepatitis B. J. Gastroenterol. Hepatol. 19,1276-1282. http://dx.doi.org/10.1111/j.1440-1746.2004.03428.x

Chan HL, Wang H, Niu J, Chim AM, Sung, JJ (2007): Two-year lamivudine treatment for hepatitis $\mathrm{B}$ e antigen-negative chronic hepatitis B: a double-blind, placebo-controlled trial. Antivir Ther. 12, 345-353.

Chang TT, Gish RG, de Man R, Gadano A, Sollano J, Chao YC, Lok AS, Han KH, Goodman Z, Zhu J, Cross A, DeHertogh D, Wilber R, Colonno R, Apelian D (2006): A comparison of entecavir and lamivudine for $\mathrm{HBeAg}$-positive chronic hepatitis B. N. Engl. J. Med. 354, 1001-1010. http://dx.doi. org/10.1056/NEJMoa051285

El-Zayadi A (2007): Hepatitis B virus infection: The Egyptian situation. Arab. J. Gastroenterol. 8, 94-98.

European Association for the Study of the Liver 2012: EASL clinical practice guidelines: management of chronic hepatitis B. J. Hepatol. 57, 167-185.

Fung SK, Chae HB, Fontana RJ, Conjeevaram H, Marrero J, Oberhelman K (2006): Virologic response and resistance to adefovir in patients with chronic hepatitis B. J. Hepatol. 44, 283-290. http://dx.doi.org/10.1016/j. jhep.2005.10.018

Hadziyannis A, Mitsoula PV, Hadziyannis SJ (2007): Prediction of longterm maintenance of virologic response during lamivudine treatment in $\mathrm{HBeAg}$ negative chronic hepatitis $\mathrm{B}$. Hepatology 46 (Suppl.), 667A.

Janssen HL, Van Zonneveld M, Senturk H, Zeuzem S, Cakaloglu Y, Simon C, So TM, Gerken G, de Man RA, Niesters HG, Zondervan P, Hansen B, Schalm SW, Akarca US (2005): Pegylated interferon alfa- $2 \mathrm{~b}$ alone or in combination with lamivudine for HBeAg-positive chronic hepatitis B: a randomised trial. Lancet 365, 123-129. http://dx.doi. org/10.1016/S0140-6736(05)17701-0

Lai CL, Gane E, Liaw YF, Hsu CW, Thongsawat S, Wang Y, Chen Y, Heathcote EJ, Rasenack J, Bzowej N, Naoumov NV, Di Bisceglie AM, Zeuzem S, Moon YM, Goodman Z, Chao G, Constance BF, Brown NA(2007): Telbivudine versus lamivudine in patients with chronic hepatitis B. N. Engl. J. Med. 357, 2576-2588. http://dx.doi.org/10.1056/ NEJMoa066422

Lau GK, Piratvisuth T, Luo KX, Marcellin P, Thongsawat S, Cooksley G, Gane E, Fried MW, Chow WC, Paik SW, Chang WY, Berg T, Flisiak R, McCloud P, Pluck N (2005): Peginter- 
feron Alfa-2a, lamivudine, and the combination for HBeAg-positive chronic hepatitis B. N. Engl. J. Med., 352, 2682-2695. http://dx.doi.org/10.1056/NEJMoa043470

Liaw YF, Gane E, Leung N, Zeuzem S, Wang Y, Lai CL, Heathcote EJ, Manns M, Bzowej N, Hwang SG, Niu J, Han SH, Cakaloglu Y, Tong MJ, Papatheodoridis G, Chen Y, Brown NA, Albanis E, Galil K, Naoumov NV (2009): A 2-Year GLOBE trial results: telbivudine is superior to lamivudine in patients with chronic hepatitis B. Gastroenterology 136, 486-495. http://dx.doi.org/10.1053/j.gastro.2008.10.026

Lok AS, McMahon BJ (2009): Chronic hepatitis B. Hepatology 45, 507-539. http://dx.doi.org/10.1002/hep.21513

Lok AS, Hussain M, Cursano C, Margotti M, Gramenzi A, Grazi GL, Jovine E, Benardi M, Andreone P (2000): Evolution of hepatitis $\mathrm{B}$ virus polymerase gene mutations in hepatitis $\mathrm{B}$ e antigen-negative patients receiving lamivudine therapy. Hepatology 32, 1145. http://dx.doi.org/10.1053/ jhep.2000.19622

Papatheodoridis GV, Dimou E, Dimakopoulos K, Manolakopoulos S, Rapti I, Kitis G, (2005): Outcome HB Ag negative chronic hepatitis $B$ on long term nucleos(t)ide analogue therapy starting with lamivudine. J. Hepatol. $42,121-129$.

Pawlotsky JM, Dusheiko G, Hatzakis A, Lau D, Lau G, Liang TJ, Locarnini S, Martin P, Richman DD, Zoulim F (2008): Virologic monitoring of hepatitis $\mathrm{B}$ virus therapy in clinical trials and practice: recommendations for a standardized approach. Gastroenterology 134, 405-415. http://dx.doi. org/10.1053/j.gastro.2007.11.036

Marcellin P, Lau GK, Bonino F, Farci P, Hadziyannis S, Jin R, Lu ZM, Piratvisuth T, Germanidid G, Yurdaydin C, Diago M, Gurel S, Lai MY, Button P, Pluck N (2004): Peg interferon alfa-2a alone, lamivudine alone, and the two in combination in patients with $\mathrm{HBeAg-negative} \mathrm{chronic}$ hepatitis B. N. Engl. J. Med. 351, 1206-1217. http://dx.doi. org/10.1056/NEJMoa040431

Marcellin P, Heathcote EJ, Corsa A, Liu Y, Miller MD, Kitrinos KM (2011): No detectable resistance to Tenofovir disoproxil fumarate (TDF) following up to 240 weeks of treatment in patients with $\mathrm{HBeAg}+$ and $\mathrm{HBeAg}$ c chronic hepatitis $\mathrm{B}$ virus infection. Hepatology 54, 480A.

Qirbi N, Hall AJ (2001): Epidemiology of hepatitis B virus infection in the Middle East. East Medit. Health J. 7, 1034-1045.

Reijnders JG, Perquin MJ, Zhang N, Hansen BE, Janssen HL (2010): Nucleos $(t)$ ide analogues only induce temporary hepatitis $\mathrm{B}$ e antigen seroconversion in most patients with chronic hepatitis B. Gastroenterology 139, 491-498. http://dx.doi. org/10.1053/j.gastro.2010.03.059

Thompson AJ, Ayres A, Yuen L, Bartholomeusz A, Bowden DS, Iser DM, Chen RY, Demediuk B, Shaw G, Bell SJ, Watson KJ, Locarnini SA, Desmond PV (2007): Lamivudine resistance in patients with chronic hepatitis B: role of clinical and virological factors. J. Gastroenterol. Hepatol. 22, 964-965. http://dx.doi.org/10.1111/j.14401746.2006.04630.x

Wiegand J, Van Bommel F, Breg T (2010): Management of chronic hepatitis B: Status and challenges beyond treatment guidelines. Semin. Liver Dis. 30, 361-377. http://dx.doi. org $/ 10.1055 / \mathrm{s}-0030-1267537$

Yi W, Liu M, H (2012): Safety of lamivudine treatment for chronic hepatitis B in early pregnancy. World J. Gastroenterol. 7, 18, 6645-6650. http://dx.doi.org/10.3748/wig.v18. i45.6645

Yim HJ, Hussain M, Liu Y, Wong SN, Fung SK, Lok AS (2006): Evolution of multi-drug resistant hepatitis B virus during sequential therapy: implications on rescue therapy. Hepatology 44, 703-712. http://dx.doi.org/10.1002/ hep. 21290

Yuen MF, Fong DY, Wong DK, Yuen JC, Fung J, Lai CL. (2007): Hepatitis B virus DNA levels at week 4 of lamivudine treatment predict the 5-year ideal response. Hepatology 46, 1695-1703. http://dx.doi.org/10.1002/hep.21939

Yuen MF, Sablon E, Hui CK, Yuan HJ, Decraemer H, Lai CL (2001): Factors associated with hepatitis B virus DNA breakthrough in patients receiving prolonged lamivudine therapy. Hepatology 34, 785-791. http://dx.doi. org/10.1053/jhep.2001.27563 